\title{
Primary Open-Angle Glaucoma
}

\author{
Young H. Kwon, M.D., Ph.D., John H. Fingert, M.D., Ph.D., Markus H. Kuehn, Ph.D., and \\ Wallace L.M. Alward, M.D. \\ Department of Ophthalmology and Visual Sciences, University of lowa, lowa City.
}

Glaucoma is a chronic, degenerative optic neuropathy that can be distinguished from most other forms of acquired optic neuropathy by the characteristic appearance of the optic nerve. In glaucoma, the neuroretinal rim of the optic nerve becomes progressively thinner, thereby enlarging the optic-nerve cup. This phenomenon is referred to as optic-nerve cupping. Its cause is the loss of retinal ganglion cell axons, along with supporting glia and vasculature. The remaining neuroretinal rim retains its normal pink color. In other optic neuropathies, the optic-nerve tissue loses its pink color and cupping does not develop. A rare exception is arteritic anterior ischemic optic neuropathy, in which cupping can occur. ${ }^{1}$ Patients with glaucoma typically lose peripheral vision and may lose all vision if not treated.

Although glaucoma frequently occurs without an elevation of intraocular pressure, the disease is nonetheless classified according to anterior-segment variations that can elevate intraocular pressure. The anterior segment of the eye has its own circulatory system, which nourishes the crystalline lens and cornea, both of which lack a blood supply. Aqueous humor, produced by the ciliary body, circulates throughout the anterior chamber and drains through the trabecular meshwork in the iridocorneal angle, which is the angle formed by the iris and cornea (Fig. 1). ${ }^{2}$ Elevated intraocular pressure does not result from increased aqueous humor production but rather from reduced aqueous outflow.

The glaucomas are classified by the appearance of the iridocorneal angle. There are openangle, closed-angle, and developmental categories, which are further divided into primary and secondary types. Primary open-angle glaucoma can occur with or without elevated intraocular pressure; the latter is sometimes called normal-tension glaucoma. Primary openangle glaucoma includes both adult-onset disease (occurring after 40 years of age) and juvenile-onset disease (occurring between the ages of 3 and 40 years of age). Examples of secondary open-angle glaucomas include those associated with exfoliation or pigmentdispersion syndrome. Closed-angle glaucoma can be primary (e.g., pupillary block) or secondary (e.g., inflammatory or neovascular causes). Developmental forms of glaucoma include primary congenital glaucoma and glaucoma associated with syndromes (e.g., aniridia or the Axenfeld-Rieger syndrome). Primary open-angle glaucoma, the predominant form of glaucoma in Western countries, probably comprises several clinically indistinguishable diseases.

In this review, we discuss primary open-angle glaucoma, in which the iridocorneal angle is open (unobstructed) and normal in appearance but aqueous outflow is diminished. We discuss the clinical features of primary open-angle glaucoma and mechanisms of elevated intraocular pressure and optic-nerve damage. To illustrate the mechanisms of elevated intraocular pressure, we focus on mutations in the myocilin (MYOC) gene. Approximately

Copyright (C) 2009 Massachusetts Medical Society. All right reserved.

Address reprint requests to Dr. Kwon at University of Iowa Health Care, 200 Hawkins Dr., Iowa City, IA 52242.

No other potential conflict of interest relevant to this article was reported. 
$4 \%$ of cases of adult-onset primary open-angle glaucoma and more than $10 \%$ of juvenileonset cases are associated with $M Y O C$ mutations. ${ }^{3,4}$ These adult-onset cases feature an elevated intraocular pressure with resultant optic-nerve damage and visual loss, and they are clinically indistinguishable from cases of primary open-angle glaucoma in patients without MYOC mutations. ${ }^{5}$ To address the mechanisms of optic-nerve damage, we broaden the discussion to include primary open-angle glaucoma with elevated intraocular pressure, with or without $M Y O C$ mutations.

\section{CLINICAL FEATURES EPIDEMIOLOGY AND RISK FACTORS}

Primary open-angle glaucoma is the second leading cause of blindness in the United States and the leading cause of blindness among black Americans. ${ }^{6}$ There is good evidence that black race, older age, elevated intraocular pressure, family history of primary open-angle glaucoma, myopia, and low diastolic perfusion pressure are risk factors for primary openangle glaucoma. ${ }^{6,7}$ (Table 1). Among patients with an elevated intraocular pressure, a relatively thin central cornea is another major risk factor for the disease. ${ }^{14}$ Evidence for other risk factors (diabetes mellitus, elevated systolic blood pressure, and migraine, among others) is less consistent. ${ }^{15}$

\section{CLINICAL PRESENTATION}

The main clinical features of primary open-angle glaucoma are an open iridocorneal angle and cupping of the optic-nerve head (or optic disk), with corresponding loss of visual field. Elevated intraocular pressure is not part of the clinical definition because primary openangle glaucoma can occur when intraocular pressure is normal (typically 10 to $21 \mathrm{~mm} \mathrm{Hg}$ ). Nevertheless, elevated intraocular pressure is an important risk fact or and is also considered to be a causative factor in glaucoma ${ }^{16}$; currently, it is the only modifiable causative factor. Many randomized clinical trials have shown that reducing intraocular pressure slows the onset and progression of glaucoma. ${ }^{17,18}$ Therefore, all current treatments of primary openangle glaucoma are aimed at reducing intraocular pressure by medical or surgical means. ${ }^{19,20}$ The Case Presentation recounts a typical presentation of primary open-angle glaucoma (see box for Case Presentation, and see Fig. 2 for examination results)

\section{MYOCILIN GENETIC FEATURES}

Juvenile-onset primary open-angle glaucoma is rare. It has the same clinical features as the adult-onset condition, except that in the juvenileonset form the intraocular pressure is often extremely high (frequently $>40 \mathrm{~mm} \mathrm{Hg}$ ) ${ }^{21}$ Large pedigrees with autosomal-dominant inheritance of juvenile-onset primary open-angle glaucoma have been reported, and analyses of genetic markers in such pedigrees have mapped a glaucomarelated gene to a region of chromosome 1q designated GLC1A. ${ }^{22}$ Subsequent linkage studies of other glaucoma pedigrees have mapped the chromosomal locations of 13 additional glaucomarelated genes (GLC1B through GLC1N). ${ }^{23}$

The relevant gene at the GLC1A locus is $M Y O C$ (Online Mendelian Inheritance in Man number, 601652), which encodes the protein myocilin. Myocilin is produced in many tissues, including the ciliary body ${ }^{24}$ and trabecular meshwork, ${ }^{25}$ the two ocular tissues that regulate intraocular pressure. ${ }^{26}$ In several studies of pedigrees, mutations in $M Y O C$ were always coinherited with juvenile-onset primary open-angle glaucoma, a strong indication that $M Y O C$ is the glaucoma gene in the GLC1A locus. ${ }^{27}$ 
The role of $M Y O C$ in the pathogenesis of the common, adult-onset form of primary openangle glaucoma has been explored by testing large cohorts of patients for mutations. A variety of $M Y O C$ mutations have been detected in 3 to $5 \%$ of patients with adult-onset primary open-angle glaucoma in cohorts around the world. ${ }^{3,27-31}$ Mutations in MYOC are among the most common causes of inherited eye disease with a known molecular basis. Mutations in other genes, including OPTN (encoding optineurin) and WDR36 (encoding a T-cell activation WD repeat-containing protein), have also been studied as potential causes of primary open-angle glaucoma. OPTN, which is in the GLC1E locus, has been associated with a small fraction of cases of low-pressure glaucoma, ${ }^{32}$ but less is known about the role of WDR36, which is in the GLC1G locus. ${ }^{33}$ These genes have recently been reviewed elsewhere. ${ }^{34}$

\section{EFFECT ON THE TRABECULAR MESHWORK}

Some $M Y O C$ mutations have been detected in a sufficient number of patients to allow identification of mutation-specific glaucoma phenotypes, including age at onset and maximum intraocular pressure. ${ }^{35,36} \mathrm{~A}$ central clinical feature of myocilin-associated glaucoma is elevated intraocular pressure, and some mutations cause higher intraocular pressure than others. Mutations associated with juvenile-onset primary openangle glaucoma lead to the greatest elevations in intraocular pressure - often more than $40 \mathrm{~mm} \mathrm{Hg}$. Mutations associated with adult-onset primary openangle glaucoma typically cause maximum pressures of 25 to $40 \mathrm{~mm} \mathrm{Hg} .{ }^{31,35}$ In patients with $M Y O C$ mutations, high intraocular pressure appears to be important not only for the onset of glaucoma but also for progression of the disease. These effects suggest that $M Y O C$ mutations encode a protein that causes microscopic abnormalities in the structures of an otherwise normal-appearing iridocorneal angle, especially the trabecular meshwork.

The function of myocilin is unknown. Analysis of its amino acid sequence has revealed functional domains, including a leucine zipper domain for protein-protein interactions and two domains that can influence protein localization. The $\mathrm{N}$-terminal of myocilin has a signal sequence that targets proteins for secretion, whereas the last three amino acids at the Cterminal of myocilin encode a sequence that directs intracellular proteins to peroxisomes. ${ }^{37}$ Wild-type myocilin protein is secreted, which suggests that the peroxisomal targeting sequence is not functional under normal circumstances. The vast majority of glaucomaassociated $M Y O C$ mutations lie within a large segment of myocilin protein that is homologous to olfactomedin proteins, a family of secreted proteins with unknown function. ${ }^{31}$

Myocilin has been detected in the trabecular meshwork, which is the principal structure of the eye that regulates intraocular pressure. ${ }^{25,38,39}$ It has also been found secreted in the growth medium of primary cultures of human trabecular-meshwork cells and in human and mouse aqueous humor, indicating that myocilin is secreted from trabecular-meshwork cells in vitro and that in vivo it is secreted from ocular tissues that may include the trabecular meshwork or ciliary body. ${ }^{38,40-42}$ Recombinant myocilin protein, myocilin in aqueous humor, and myocilin in medium from cultured cells can self-associate and form multimers. $^{25,38,43}$

\section{DECREASED SECRETION}

$M Y O C$ mutations do not appear to cause glaucoma as a result of haploinsufficiency or overexpression. Deficiencies in myocilin production resulting from a hemizygous deletion ${ }^{44}$ or a presumed homozygous null mutation (i.e., Arg46Stop) ${ }^{45}$ do not cause glaucoma. Similarly, glaucoma does not develop in mice with overexpression of myocilin or with deficient myocilin production. ${ }^{46,47}$ These results suggest that disease-causing mutations alter 
the myocilin protein in such a way that it disrupts the regulation of intraocular pressure. Indeed, $M Y O C$ mutations associated with glaucoma do alter the properties of the protein disease-associated mutations reduce the solubility of myocilin in a detergent, whereas benign sequence polymorphisms have no such effect. ${ }^{48}$ Glaucomaassociated mutations also reduce the secretion of myocilin in vitro and in vivo. Secretion of myocilin is dramatically reduced in trabecular-meshwork cells cultured from patients with glaucoma-associated MYOC mutations. ${ }^{40}$ Similarly, MYOC mutations greatly reduce the quantity of myocilin that is secreted into the aqueous humor, ${ }^{40}$ supporting the idea that failure to secrete myocilin is a central feature in the pathogenesis of myocilin-associated glaucoma (Fig. 3).

MYOC mutations may prevent the secretion of myocilin by exposing a cryptic domain that directs proteins to peroxisomes, and there is evidence that mutant myocilin may be retained within the intracellular space by means of an abnormal association with proteins of the peroxisome-targeting system. ${ }^{49}$ Other studies in mice have shown that mutations in the murine myocilin gene (Myoc) can inhibit secretion of myocilin and cause some signs of glaucoma without a cryptic targeting domain. ${ }^{50}$ Regardless of the mechanism of retention, decreased secretion and increased accumulation of intracellular myocilin appear to be initial steps in the pathogenesis of myocilin-associated glaucoma.

Injury or death of trabecular-meshwork cells has been implicated in the pathogenesis of open-angle glaucoma. ${ }^{51}$ Endothelial cells of the trabecular meshwork maintain its structure and facilitate the outflow of aqueous humor from the eye by remodeling this porous tissue and preventing debris from occluding the outflow pathway. A reduction in cellularity and alterations in the architecture of the trabecular meshwork have been observed in glaucoma, ${ }^{52}$ and these changes may increase resistance to aqueous outflow, thereby elevating intraocular pressure and eventually damaging the optic nerve. ${ }^{51,53}$ Mutant myocilin that accumulates in the intracellular space may be toxic to trabecular-meshwork cells, initiating a cascade of events that begins with loss of function in these cells, which damages the outflow pathway and results in elevated intraocular pressure. The finding that aqueous humor outflow is reduced in patients with $M Y O C$ mutations supports this hypothesis. ${ }^{54}$ The development of animal models of myocilin-associated glaucoma $50,55,56$ provides new tools for exploring the effects of mutations in the myocilin gene on the structure and function of the outflow pathway at the tissue, cellular, and subcellular levels. In particular, these animal models will facilitate studies of the effects of MYOC mutations on the health and numbrs of trabecular-meshwork cells and the organization of the extracellular structure of the trabecular meshwork.

\section{DAMAGE TO THE OPTIC-NERVE HEAD}

It is generally believed that elevated intraocular pressure - regardless of its cause triggers a common set of cellular events. The optic-nerve head consists of axons projected from retinal ganglion cells, which exit the eye through the lamina cribrosa, a collagenous structure with sievelike openings (Fig. 4A). The lamina cribrosa separates unmyelinated prelaminar retinal ganglion-cell axons from myelinated postlaminar retinal ganglion-cell axons. The optic-nerve head also contains retinal vasculature (the central retinal artery and vein) and such glial elements as microglia, astrocytes, and oligodendrocytes (the oligodendrocytes are present only in the postlaminar region and are important in postlaminar axon myelination). ${ }^{57,58} \mathrm{We}$ outline several key mechanisms of optic-nerve damage that are caused by elevated intraocular pressure, although damage that is independent of elevated intraocular pressure may also occur in primary openangle glaucoma. We limit the discussion to recent literature; more comprehensive reviews of the subject can be found elsewhere. ${ }^{59-61}$ 


\section{CELLULAR STRESS}

Elevated intraocular pressure has direct effects on retinal ganglion cells. Axonal transport decreases in the presence of elevated intraocular pressure. ${ }^{62}$ The reduced retrograde axoplasmic flow can stress retinal ganglion cells and cause their death from deprivation of neurotrophic factors such as brain-derived neurotrophic factor. ${ }^{62-64}$ If blood perfusion at the optic-nerve head is persistently reduced, ${ }^{65-67}$ tissue hypoxia can induce the formation and accumulation of reactive oxygen species in the retina, and this accumulation causes cellular stress and malfunction. ${ }^{6}$ In glaucoma, proteins and lipids with oxidative modifications accumulate in the retina and optic-nerve head, and antioxidant treatments have some benefit in animal models. ${ }^{69-73}$ The use of microarray technology in animal models has shown that changes in the gene-expression profile of the retina occur rapidly in response to elevated intraocular pressure. ${ }^{74,75}$ These changes include decreased expression of many genes specific to retinal ganglion cells ${ }^{74,76-79}$ and increased expression of markers of hypoxia and glial activation. ${ }^{65,80,81}$

Glial cells in the optic-nerve head (microglia and astrocytes) become activated in response to the elevated intraocular pressure in glaucoma ${ }^{82-85}$ (Fig. 4B). Activated astrocytes synthesize molecules that lead to degradation and remodeling of the extracellular matrix, and these changes can have biomechanical effects on the optic-nerve head that in turn increase stress on retinal ganglion-cell axons. ${ }^{86,87}$ In a mouse model of glaucoma, activated glial cells released tumor necrosis factor a (TNF-a), a proinflammatory cytokine. ${ }^{88}$ Deletion of the genes encoding TNF- $a$ or its receptor increased the survival of retinal ganglion cells in this model. ${ }^{88,89}$ Intravitreal injection of TNF-a causes loss of retinal ganglion-cell axons and subsequently loss of entire cells, even in the absence of elevated intraocular pressure. These results suggest that TNF- $a$ can be a mediator of damage of retinal ganglion-cell axons when intraocular pressure is elevated. The presence of TNF- $a$ in human glaucomatous retina ${ }^{90}$ and optic-nerve head ${ }^{91}$ has been detected by immunohistochemical analysis. Collectively, this evidence suggests that glial activation and TNF- $\alpha$ are important mediators of damage to retinal ganglion-cell axons. ${ }^{88,90,91}$

\section{STRUCTURAL CHANGES}

Cupping of the optic-nerve head results from the loss of prelaminar tissue and posterior deformation of the lamina cribrosa. Three-dimensional histomorphometric studies of primates with experimentally induced glaucoma raised the possibility that one of the early changes in the structure of the optic-nerve head in glaucoma is the thickening - rather than thinning — of prelaminar tissue. ${ }^{87,92}$ This change is accompanied by microglial proliferation. ${ }^{93}$ Subsequently, the lamina cribrosa bows posteriorly (Fig. 4C). These changes in the lamina cribrosa, combined with the eventual loss of prelaminar tissue, make the cup larger and deeper. The biomechanical consequences of these changes are believed to strain retinal ganglion-cell axons, which further compromises their function. ${ }^{87}$ These morphologic findings are accompanied by changes in the composition of the extracellular matrix of the optic-nerve head, including increased synthesis of collagen IV, proteoglycans, adhesion molecules, and matrix metalloproteinases and a loss of gap-junction communication that accompanies astrocyte activation. ${ }^{83,86,94,95}$

\section{DAMAGE TO RETINAL GANGLION-CELL AXONS}

Clinical observations have indicated that the optic-nerve head, and more specifically the lamina cribrosa, is the initial site of glaucomatous damage. ${ }^{96}$ In animal models, and presumably also in human glaucoma, damage to retinal ganglion-cell axons precedes the death of the cells ${ }^{97,98}$ (Fig. 4B and 4C). In the DBA2/J mouse strain, elevated intraocular pressure develops spontaneously at 7 to 9 months of age, and soon thereafter, axonal shrinkage and decreased retrograde transport occur, even though the soma of the retinal 
ganglion cells appears normal. ${ }^{99}$ In these mice, the retinal ganglion-cell axons proximal to the point of my-elination survive, suggesting that damage to the axons occurs in an area that corresponds to the lamina cribrosa in primates. ${ }^{77,97}$ However, retinal ganglion cells survive for only about 1 to 2 months after axonal degeneration. ${ }^{77,97}$ Thus, the degradation of the retinal ganglion-cell axon and soma may involve separate mechanisms. ${ }^{100}$ In DBA/2 mice, damage to retinal ganglion-cell axons occurs despite the absence of the collagenous lamina cribrosa plates typically found in primates. ${ }^{101}$ This finding suggests that a cell-mediated mechanism underlies the damage, perhaps involving excessive synthesis of extracellular matrix material ${ }^{83,86,94,95}$ or elevation of intra-axonal calcium levels resulting from overexpression of ephrin-B2 (a receptor tyrosine kinase in glioma cells). ${ }^{102,103}$

\section{LOSS OF RETINAL GANGLION CELLS}

Axonal damage and chronic stress result in the death of retinal ganglion cells. Most, if not all, of the loss of retinal ganglion cells in the glaucomatous retina occurs through apoptosis. ${ }^{104,105}$ Inhibition of apoptosis by deletion of the Bax gene in a mouse model of glaucoma almost completely rescues the retinal ganglion-cell soma, but axons are not preserved. ${ }^{100}$ By means of noninvasive direct imaging of apoptotic cell death, ${ }^{106}$ it has been possible to observe progressive loss of retinal ganglion-cell axons and cell bodies in a rat model of glaucoma. Coupled with thinning and further posterior bowing of the lamina cribrosa, apoptotic loss of the retinal ganglion cells results in a large, deep cup, as seen clinically in advanced glaucoma (Fig. 4D).

Retinal ganglion-cell death is not accompanied by prominent infiltration of mononuclear cells, although there is indirect evidence of inflammatory processes, as indicated by the presence of autoantibodies against retinal antigens in patients with glaucoma. ${ }^{81}$ Instead, glial cells phagocytose cellular debris and initiate a scar response after retinal ganglion-cell death. Inflammation-like glial activity is frequently observed in degenerative disorders of the central nervous system and is referred to as neuroinflammation, a process distinct from the adaptive immune response and more akin to a reaction of the innate immune system. ${ }^{107} \mathrm{In}$ glaucoma, glial expression of major-histocompatibility-complex (MHC) class II molecules 108 and synthesis of components of the complement cascade 109,110 occur as retinal ganglion-cell death continues, and these processes may further contribute to the degeneration of retinal ganglion cells.

\section{CONCLUSIONS}

In glaucoma, a major cause of blindness, the ganglion-cell axons that make up the optic nerve are damaged by a variety of factors, only some of which are understood. The most important risk factor for glaucoma is elevated intraocular pressure. Because the optic-nerve damage in glaucoma is not yet amenable to direct treatment, we provide treatment for the only known risk factor that can be modified, elevated intraocular pressure. As more is understood about the molecular biology of the trabecular meshwork and optic nerve in health and disease, our ability to treat glaucoma will likely improve.

\section{Acknowledgments}

Supported in part by grants from the Marlene S. and Leonard A. Hadley Glaucoma Research Fund and Research to Prevent Blindness. Dr. Kwon received support from the Clifford M. and Ruth M. Altermatt Professorship, and Dr. Alward received support from the Frederick C. Blodi Chair.

Dr. Fingert reports receiving grant support from Alcon Research and holding several unlicensed patents related to gene discovery in glaucoma, and Dr. Alward reports holding an unlicensed patent for the diagnosis of $M Y O C$ mutations. 
We thank Patricia Duffel, R.Ph., M.A., for her assistance with the preparation of the manuscript.

\section{REFERENCES}

1. Hayreh SS, Jonas JB. Optic disc morphology after arteritic anterior ischemic optic neuropathy. Ophthalmology. 2001; 108:1586-1594. [PubMed: 11535455]

2. Alward WL. Biomedicine: a new angle on ocular development. Science. 2003; 299:1527-1528. [PubMed: 12624251]

3. Fingert JH, Héon E, Liebmann JM, et al. Analysis of myocilin mutations in 1703 glaucoma patients from five different populations. Hum Mol Genet. 1999; 8:899-905. [PubMed: 10196380]

4. Aldred MA, Baumber L, Hill A, et al. Low prevalence of MYOC mutations in UK primary openangle glaucoma patients limits the utility of genetic testing. Hum Genet. 2004; 115:428-431. [PubMed: 15338275]

5. Graul TA, Kwon YH, Zimmerman MB, et al. A case-control comparison of the clinical characteristics of glaucoma and ocular hypertensive patients with and without the myocilin Gln368Stop mutation. Am J Ophthalmol. 2002; 134:884-890. [PubMed: 12470758]

6. Kwon, YH.; Caprioli, J. Primary open angle glaucoma. In: Tasman, W.; Jaeger, EA., editors. Duane's clinical ophthalmology. Philadelphia: J.B. Lippincott; 1999. p. 1-30.

7. Alward, WLM. Open angle glaucomas. In: Alward, WLM., editor. Glaucoma: the requisites in ophthalmology. Mosby: St. Louis; 2000. p. 128-140.

8. Rudnicka AR, Mt-Isa S, Owen CG, Cook DG, Ashby D. Variations in primary open-angle glaucoma prevalence by age, gender, and race: a Bayesian meta-analysis. Invest Ophthalmol Vis Sci. 2006; 47:4254-4261. [PubMed: 17003413]

9. Sommer A, Tielsch JM, Katz J, et al. Relationship between intraocular pressure and primary open angle glaucoma among white and black Americans: the Baltimore Eye Survey. Arch Ophthalmol. 1991; 109:1090-1095. [PubMed: 1867550]

10. Tielsch JM, Katz J, Sommer A, Quigley HA, Javitt JC. Hypertension, perfusion pressure, and primary open-angle glaucoma: a population-based assessment. Arch Ophthalmol. 1995; 113:216221. [PubMed: 7864755]

11. Idem. Family history and risk of primary open angle glaucoma: the Baltimore Eye Survey. Arch Ophthalmol. 1994; 112:69-73. [PubMed: 8285897]

12. Mitchell P, Hourihan F, Sandbach J, Wang JJ. The relationship between glaucoma and myopia: the Blue Mountains Eye Study. Ophthalmology. 1999; 106:2010-2015. [PubMed: 10519600]

13. Wong TY, Klein BE, Klein R, Knudtson M, Lee KE. Refractive errors, intraocular pressure, and glaucoma in a white population. Ophthalmology. 2003; 110:211-217. [PubMed: 12511368]

14. Gordon MO, Beiser JA, Brandt JD, et al. The Ocular Hypertension Treatment Study: baseline factors that predict the onset of primary open-angle glaucoma. Arch Ophthalmol. 2002; 120:714720. [PubMed: 12049575]

15. Allingham, RR.; Damji, KF.; Freedman, S.; Moroi, SE.; Shafranov, G.; Shields, MB., editors. Clinical epidemiology of glaucoma. Shields' textbook of glaucoma. 5th ed.. Philadelphia: Lippincott Williams \& Wilkins; 2005. p. 170-190.

16. Bahrami H. Causal inference in primary open angle glaucoma: specific discussion on intraocular pressure. Ophthal-mic Epidemiol. 2006; 13:283-289.

17. Heijl A, Leske MC, Bengtsson B, Hy-man L, Bengtsson B, Hussein M. Reduction of intraocular pressure and glaucoma progression: results from the Early Manifest Glaucoma Trial. Arch Ophthalmol. 2002; 120:1268-1279. [PubMed: 12365904]

18. Kass MA, Heuer DK, Higginbotham EJ, et al. The Ocular Hypertension Treatment Study: a randomized trial determines that topical ocular hypotensive medication delays or prevents the onset of primary open-angle glaucoma. Arch Ophthal-mol. 2002; 120:701-713.

19. Alward WL. Medical management of glaucoma. N Engl J Med. 1998; 339:1298-1307. [PubMed: 9791148]

20. Weinreb RN, Khaw PT. Primary open-angle glaucoma. Lancet. 2004; 363:1711-17120. [PubMed: 15158634] 
21. Johnson AT, Richards JE, Boehnke M, et al. Clinical phenotype of juvenile-onset primary openangle glaucoma linked to chromosome 1q. Ophthalmology. 1996; 103:808-814. [PubMed: 8637692]

22. Sheffield VC, Stone EM, Alward WL, et al. Genetic linkage of familial open angle glaucoma to chromosome 1q21-q31. Nat Genet. 1993; 4:47-50. [PubMed: 8513321]

23. Wiggs JL. Genetic etiologies of glaucoma. Arch Ophthalmol. 2007; 125:30-37. [PubMed: 17210849]

24. Ortego J, Escribano J, Coca-Prados M. Cloning and characterization of subtracted cDNAs from a human ciliary body library encoding TIGR, a protein involved in juvenile open angle glaucoma with homology to myosin and olfactomedin. FEBS Lett. 1997; 413:349-353. [PubMed: 9280311]

25. Polansky JR, Fauss DJ, Chen P, et al. Cellular pharmacology and molecular biology of the trabecular meshwork inducible glucocorticoid response gene product. Ophthalmologica. 1997; 211:126-139. [PubMed: 9176893]

26. Kubota R, Noda S, Wang Y, et al. A novel myosin-like protein (myocilin) expressed in the connecting cilium of the photoreceptor: molecular cloning, tissue expression, and chromosomal mapping. Genomics. 1997; 41:360-369. [PubMed: 9169133]

27. Stone EM, Fingert JH, Alward WL, et al. Identification of a gene that causes primary open angle glaucoma. Science. 1997; 275:668-670. [PubMed: 9005853]

28. Wiggs JL, Allingham RR, Vollrath D, et al. Prevalence of mutations in TIGR/ Myocilin in patients with adult and juvenile primary open-angle glaucoma. Am J Hum Genet. 1998; 63:1549-1552. [PubMed: 9792882]

29. Stoilova D, Child A, Brice G, et al. Novel TIGR/MYOC mutations in families with juvenile onset primary open angle glaucoma. J Med Genet. 1998; 35:989-992. [PubMed: 9863594]

30. Adam MF, Belmouden A, Binisti P, et al. Recurrent mutations in a single exon encoding the evolutionarily conserved olfactomedin-homology domain of TIGR in familial open-angle glaucoma. Hum Mol Genet. 1997; 6:2091-2097. [PubMed: 9328473]

31. Fingert JH, Stone EM, Sheffield VC, Alward WL. Myocilin glaucoma. Surv Ophthalmol. 2002; 47:547-561. [PubMed: 12504739]

32. Rezaie T, Child A, Hitchings R, et al. Adult-onset primary open-angle glaucoma caused by mutations in optineurin. Science. 2002; 295:1077-1079. [PubMed: 11834836]

33. Monemi S, Spaeth G, DaSilva A, et al. Identification of a novel adult-onset primary open-angle glaucoma (POAG) gene on 5q22.1. Hum Mol Genet. 2005; 14:725-733. [PubMed: 15677485]

34. Challa P. Gl aucoma genetics. Int Oph-thalmol Clin. 2008; 48(4):73-94.

35. Alward WLM, Fingert JH, Coote MA, et al. Clinical features associated with mutations in the chromosome 1 openangle glaucoma gene (GLC1A). N Engl J Med. 1998; 338:1022-1027. [PubMed: 9535666]

36. Allingham RR, Wiggs JL, De La Paz MA, et al. Gln368STOP myocilin mutation in families with late-onset primary open-angle glaucoma. Invest Ophthalmol Vis Sci. 1998; 39:2288-2295. [PubMed: 9804137]

37. Fingert JH, Ying L, Swiderski RE, et al. Characterization and comparison of the human and mouse GLC1A glaucoma genes. Genome Res. 1998; 8:377-384. [PubMed: 9548973]

38. Nguyen TD, Chen P, Huang WD, Chen H, Johnson D, Polansky JR. Gene structure and properties of TIGR, an olfactomedin-related glycoprotein cloned from glucocorticoid-induced trabecular meshwork cells. J Biol Chem. 1998; 273:6341-6350. [PubMed: 9497363]

39. Lütjen-Drecoll E, May CA, Polansky JR, Johnson DH, Bloemendal H, Nguyen TD. Localization of the stress proteins alpha B-crystallin and trabecular mesh-work inducible glucocorticoid response protein in normal and glaucomatous trabecular meshwork. Invest Ophthalmol Vis Sci. 1998; 39:517-525. [PubMed: 9501861]

40. Jacobson N, Andrews M, Shepard AR, et al. Non-secretion of mutant proteins of the glaucoma gene myocilin in cultured trabecular meshwork cells and in aqueous humor. Hum Mol Genet. 2001; 10:117-125. [PubMed: 11152659]

41. O'Brien TE, Metheney CD, Polansky JR. Immunofluorescence method for quantifying the trabecular meshwork glucocorticoid response (TIGR) protein in trabecular meshwork and Schlemm's canal cells. Curr Eye Res. 1999; 19:517-524. [PubMed: 10550794] 
42. Wordinger RJ, Clark AF. Effects of glucocorticoids on the trabecular meshwork: towards a better understanding of glaucoma. Prog Retin Eye Res. 1999; 18:629-667. [PubMed: 10438153]

43. Gobeil S, Rodrigue MA, Moisan S, et al. Intracellular sequestration of heterooligomers formed by wild-type and glaucoma-causing myocilin mutants. Invest Ophthalmol Vis Sci. 2004; 45:3560_ 3567. [PubMed: 15452063]

44. Wiggs JL, Vollrath D. Molecular and clinical evaluation of a patient hemizy- gous for TIGR/ MYOC. Arch Ophthalmol. 2001; 119:1674-1678. [PubMed: 11709019]

45. Lam DS, Leung YF, Chua JK, et al. Truncations in the TIGR gene in individuals with and without primary open-angle glaucoma. Invest Ophthalmol Vis Sci. 2000; 41:1386-1391. [PubMed: 10798654]

46. Kim BS, Savinova OV, Reedy MV, et al. Targeted disruption of the myocilin gene (Myoc) suggests that human glaucomacausing mutations are gain of function. Mol Cell Biol. 2001; 21:7707-7713. [PubMed: 11604506]

47. Gould DB, Miceli-Libby L, Savinova OV, et al. Genetically increasing Myoc expression supports a necessary pathologic role of abnormal proteins in glaucoma. Mol Cell Biol. 2004; 24:90199025. [PubMed: 15456875]

48. Zhou Z, Vollrath D. A cellular assay distinguishes normal and mutant TIGR/ myocilin protein. Hum Mol Genet. 1999; 8:2221-2228. [PubMed: 10545602]

49. Shepard AR, Jacobson N, Millar JC, et al. Glaucoma-causing myocilin mutants require the peroxisomal targeting signal-1 receptor (PTS1R) to elevate intraocular pressure. Hum Mol Genet. 2007; 16:609-617. [PubMed: 17317787]

50. Senatorov V, Malyukova I, Fariss R, et al. Expression of mutated mouse myocilin induces openangle glaucoma in transgenic mice. J Neurosci. 2006; 26:11903-11914. [PubMed: 17108164]

51. Alvarado J, Murphy C, Juster R. Trabecular meshwork cellularity in primary openangle glaucoma and nonglaucomatous normals. Ophthalmology. 1984; 91:564-579. [PubMed: 6462622]

52. Lütjen-Drecoll, E.; Rohen, JW. Morphology of aqueous outflow pathways in normal and glaucomatous eyes. In: Ritch, R.; Shields, MB.; Krupin, T., editors. The glaucomas. 2nd ed.. Mosby: St. Louis; 1996. p. 89-123.

53. Rodrigues MM, Spaeth GL, Sivalingam E, Weinreb S. Histopathology of 150 trabeculectomy specimens in glaucoma. Trans Ophthalmol Soc U K. 1976; 96:245-255. [PubMed: 1070878]

54. Wilkinson $\mathrm{CH}$, van der Straaten $\mathrm{D}$, Craig JE, et al. Tonography demonstrates reduced facility of outflow of aqueous humor in myocilin mutation carriers. J Glaucoma. 2003; 12:237-242. [PubMed: 12782842]

55. Zhou Y, Grinchuk O, Tomarev SI. Transgenic mice expressing the Tyr437His mutant of human myocilin protein develop glaucoma. Invest Ophthalmol Vis Sci. 2008; 49:1932-1939. [PubMed: 18436825]

56. Paper W, Kroeber M, Heersink S, et al. Elevated amounts of myocilin in the aqueous humor of transgenic mice cause significant changes in ocular gene expression. Exp Eye Res. 2008; 87:257267. [PubMed: 18602390]

57. Minckler DS, McLean IW, Tso MO. Distribution of axonal and glial elements in the rhesus optic nerve head studied by electron microscopy. Am J Ophthalmol. 1976; 82:179-187. [PubMed: 821348]

58. Zhang, J.; Rubin, RM.; Rao, NA. Anatomy and embryology of the optic nerve. In: Tasman, W.; Jaeger, EA., editors. Duane's foundations of clinical ophthalmology. Philadelphia: Lippincott Williams \& Wilkins; 2005. p. 1-10.

59. Kuehn MH, Fingert JH, Kwon YH. Retinal ganglion cell death in glaucoma: mechanisms and neuroprotective strategies. Ophtha lmol Clin North Am. 2005; 18:383-395.

60. Vrabec JP, Levin LA. The neurobiology of cell death in glaucoma. Eye. 2007; 21(Suppl 1):S11S14. [PubMed: 18157171]

61. Wax MB, Tezel G. Neurobiology of glaucomatous optic neuropathy: diverse cellular events in neurodegeneration and neuroprotection. Mol Neurobiol. 2002; 26:45-55. [PubMed: 12392055]

62. Quigley HA, McKinnon SJ, Zack DJ, et al. Retrograde axonal transport of BDNF in retinal ganglion cells is blocked by acute IOP elevation in rats. Invest Ophthalmol Vis Sci. 2000; 41:3460-3466. [PubMed: 11006239] 
63. Pease ME, McKinnon SJ, Quigley HA, Kerrigan-Baumrind LA, Zack DJ. Obstructed axonal transport of BDNF and its receptor TrkB in experimental glaucoma. Invest Ophthalmol Vis Sci. 2000; 41:764-774. [PubMed: 10711692]

64. Balaratnasingam C, Morgan WH, Bass L, Matich G, Cringle SJ, Yu DY. Ax-onal transport and cytoskeletal changes in the laminar regions after elevated intraocular pressure. Invest Ophthalmol Vis Sci. 2007; 48:3632-3644. [PubMed: 17652733]

65. Rajendram R, Rao NA. Neuroglobin in normal retina and retina from eyes with advanced glaucoma. Br J Ophthalmol. 2007; 91:663-666. [PubMed: 17151062]

66. Tezel G, Wax MB. Hypoxia-inducible factor 1alpha in the glaucomatous retina and optic nerve head. Arch Ophthalmol. 2004; 122:1348-1356. [PubMed: 15364715]

67. Mozaffarieh M, Grieshaber MC, Flammer J. Oxygen and blood flow: players in the pathogenesis of glaucoma. Mol Vis. 2008; 14:224-233. [PubMed: 18334938]

68. Ko ML, Peng PH, Ma MC, Ritch R, Chen CF. Dynamic changes in reactive oxygen species and antioxidant levels in retinas in experimental glaucoma. Free Radic Biol Med. 2005; 39:365-373. [PubMed: 15993335]

69. Tezel G, Yang X, Cai J. Proteomic identification of oxidatively modified retinal proteins in a chronic pressure-induced rat model of glaucoma. Invest Ophthalmol Vis Sci. 2005; 46:3177-3187. [PubMed: 16123417]

70. Liu Q, Ju WK, Crowston JG, et al. Oxidative stress is an early event in hydrostatic pressure induced retinal ganglion cell damage. Invest Ophthalmol Vis Sci. 2007; 48:4580-4589. [PubMed: 17898281]

71. Moreno MC, Campanelli J, Sande P, Sánez DA, Keller Sarmiento MI, Rosen-stein RE. Retinal oxidative stress induced by high intraocular pressure. Free Radic Biol Med. 2004; 37:803-812. [PubMed: 15384194]

72. Tezel G, Luo C, Yang X. Accelerated aging in glaucoma: immunohistochemical assessment of advanced glycation end products in the human retina and optic nerve head. Invest Ophthalmol Vis Sci. 2007; 48:1201-1211. [PubMed: 17325164]

73. Munemasa Y, Ahn JH, Kwong JM, Caprioli J, Piri N. Redox proteins thiore- doxin 1 and thioredoxin 2 support retinal ganglion cell survival in experimental glaucoma. Gene Ther. 2009; 16:17-25. [PubMed: 18701913]

74. Yang Z, Quigley HA, Pease ME, et al. Changes in gene expression in experimental glaucoma and optic nerve transection: the equilibrium between protective and detrimental mechanisms. Invest Oph-thalmol Vis Sci. 2007; 48:5539-5548.

75. Ahmed F, Brown KM, Stephan DA, Morrison JC, Johnson EC, Tomarev SI. Microarray analysis of changes in mRNA levels in the rat retina after experimental elevation of intraocular pressure. Invest Ophthalmol Vis Sci. 2004; 45:1247-1258. [PubMed: 15037594]

76. Kim CY, Kuehn MH, Clark AF, Kwon YH. Gene expression profile of the adult human retinal ganglion cell layer. Mol Vis. 2006; 12:1640-1648. [PubMed: 17200664]

77. Soto I, Oglesby E, Buckingham BP, et al. Retinal ganglion cells downregulate gene expression and lose their axons within the optic nerve head in a mouse glaucoma model. J Neurosci. 2008; 28:548-561. [PubMed: 18184797]

78. Huang W, Fileta J, Guo Y, Grosskreutz CL. Downregulation of Thy1 in retinal ganglion cells in experimental glaucoma. Curr Eye Res. 2006; 31:265-271. [PubMed: 16531284]

79. Schlamp CL, Johnson EC, Li Y, Morrison JC, Nickells RW. Changes in Thy1 gene expression associated with damaged retinal ganglion cells. Mol Vis. 2001; 7:192-201. [PubMed: 11509915]

80. Steele MR, Inman DM, Calkins DJ, Horner PJ, Vetter ML. Microarray analysis of retinal gene expression in the DBA/2J model of glaucoma. Invest Ophthalmol Vis Sci. 2006; 47:977-985. [PubMed: 16505032]

81. Tezel G, Wax MB. The immune system and glaucoma. Curr Opin Ophthal-mol. 2004; 15:80-84.

82. Pena JD, Varela HJ, Ricard CS, Hernandez MR. Enhanced tenascin expression associated with reactive astrocytes in human optic nerve heads with primary open angle glaucoma. Exp Eye Res. 1999; 68:29-40. [PubMed: 9986739] 
83. Agapova OA, Ricard CS, Salvador-Silva M, Hernandez MR. Expression of matrix metalloproteinases and tissue inhibitors of metalloproteinases in human optic nerve head astrocytes. Glia. 2001; 33:205-216. [PubMed: 11241738]

84. Hernandez MR, Agapova OA, Yang P, Salvador-Silva M, Ricard CS, Aoi S. Differential gene expression in astrocytes from human normal and glaucomatous optic nerve head analyzed by cDNA microarray. Glia. 2002; 38:45-64. [PubMed: 11921203]

85. Yang P, Agapova O, Parker A, et al. DNA microarray analysis of gene expression in human optic nerve head astrocytes in response to hydrostatic pressure. Physiol Genomics. 2004; 17:157-169. [PubMed: 14747662]

86. Hernandez MR. The optic nerve head in glaucoma: role of astrocytes in tissue remodeling. Prog Retin Eye Res. 2000; 19:297-321. [PubMed: 10749379]

87. Burgoyne CF, Downs JC. Premise and prediction: how optic nerve head biome- chanics underlies the susceptibility and clinical behavior of the aged optic nerve head. J Glaucoma. 2008; 17:318328. [PubMed: 18552618]

88. Nakazawa T, Nakazawa C, Matsubara A, et al. Tumor necrosis factor-alpha mediates oligodendrocyte death and delayed retinal ganglion cell loss in a mouse model of glaucoma. J Neurosci. 2006; 26:12633-12641. [PubMed: 17151265]

89. Kitaoka Y, Kwong JM, Ross-Cisneros FN, et al. TNF-alpha-induced optic nerve degeneration and nuclear factor-kappaB p65. Invest Ophthalmol Vis Sci. 2006; 47:1448-1457. [PubMed: $16565378]$

90. Tezel G, Li LY, Patil RV, Wax MB. TNF -alpha and TNF-alpha receptor-1 in the retina of normal and glaucomatous eyes. Invest Ophthalmol Vis Sci. 2001; 42:1787-1794. [PubMed: 11431443]

91. Yan X, Tezel G, Wax MB, Edward DP. Matrix metalloproteinases and tumor necrosis factor alpha in glaucomatous optic nerve head. Arch Ophthalmol. 2000; 118:666-673. [PubMed: 10815159]

92. Yang H, Downs JC, Bellezza A, Thompson H, Burgoyne CF. 3-D histomorphometry of the normal and early glaucomatous monkey optic nerve head: prelaminar neural tissues and cupping. Invest Ophthalmol Vis Sci. 2007; 48:5068-5084. [PubMed: 17962459]

93. Johnson EC, Jia L, Cepurna WO, Doser TA, Morrison JC. Global changes in optic nerve head gene expression after exposure to elevated intraocular pressure in a rat glaucoma model. Invest Ophthalmol Vis Sci. 2007; 48:3161-3177. [PubMed: 17591886]

94. Malone P, Miao H, Parker A, Juarez S, Hernandez MR. Pressure induces loss of gap junction communication and redistribution of connexin 43 in astrocytes. Glia. 2007; 55:1085-1098. [PubMed: 17551925]

95. Morrison JC, Dorman-Pease ME, Dunkelberger GR, Quigley HA. Optic nerve head extracellular matrix in primar y optic atrophy and experimental glaucoma. Arch Ophthalmol. 1990; 108:1020 1024. [PubMed: 2369339]

96. Quigley HA. Neuronal death in glaucoma. Prog Retin Eye Res. 1999; 18:39-57. [PubMed: 9920498]

97. Howell GR, Libby RT, Jakobs TC, et al. Axons of retinal ganglion cells are insulted in the optic nerve early in DBA/2J glaucoma. J Cell Biol. 2007; 179:1523-1537. [PubMed: 18158332]

98. Schlamp CL, Li Y, Dietz JA, Janssen KT, Nickells RW. Progressive ganglion cell loss and optic nerve degeneration in DBA/2J mice is variable and asymmetric. BMC Neurosci. 2006; 7:66. [PubMed: 17018142]

99. Jakobs TC, Libby RT, Ben Y, John SW, Masland RH. Retinal ganglion cell degeneration is topological but not cell type specific in DBA/2J mice. J Cell Biol. 2005; 171:313-325. [PubMed: 16247030]

100. Libby RT, Li Y, Savinova OV, et al. Susceptibility to neurodegeneration in a glaucoma is modified by Bax gene dosage. PLoS Genet. 2005; 1:17-26. [PubMed: 16103918]

101. May CA, Lutjen-Drecoll E. Morphology of the murine optic nerve. Invest Ophthalmol Vis Sci. 2002; 43:2206-2212. [PubMed: 12091418]

102. Du J, Tran T, Fu C, Sretavan DW. Upregulation of EphB2 and ephrin-B2 at the optic nerve head of DBA/2J glaucomatous mice coincides with axon loss. Invest Ophthalmol Vis Sci. 2007; 48:5567-5581. [PubMed: 18055806] 
103. Pena JD, Agapova O, Gabelt BT, et al. Increased elastin expression in astrocytes of the lamina cribrosa in response to elevated intraocular pressure. Invest Oph-thalmol Vis Sci. 2001; 42:23032314.

104. Kerrigan LA, Zack DJ, Quigley HA, Smith SD, Pease ME. TUNEL-positive ganglion cells in human primary open-angle glaucoma. Arch Ophthalmol. 1997; 115:1031-1035. [PubMed: 9258226]

105. Quigley HA, Nickells RW, Kerrigan LA, Pease ME, Thibault DJ, Zack DJ. Retinal ganglion cell death in experimental glaucoma and after axotomy occurs by apoptosis. Invest Ophthalmol Vis Sci. 1995; 36:774-786. [PubMed: 7706025]

106. Cordeiro MF, Guo L, Luong V, et al. Real-time imaging of single nerve cell apoptosis in retinal neurodegeneration. Proc Natl Acad Sci U S A. 2004; 101:13352-13356. [PubMed: 15340151]

107. Streit WJ, Mrak RE, Griffin WS. Microglia and neuroinflammation: a pathological perspective. J Neuroinflammation. 2004; 1:14. [PubMed: 15285801]

108. Yang J, Yang P, Tezel G, Patil RV, Hernandez MR, Wax MB. Induction of HLA-DR expression in human lamina cri-brosa astrocytes by cytokines and simulated ischemia. Invest Ophthalmol Vis Sci. 2001; 42:365-371. [PubMed: 11157868]

109. Stasi K, Nagel D, Yang X, et al. Complement component 1Q (C1Q) upregulation in retina of murine, primate, and human glaucomatous eyes. Invest Ophthalmol Vis Sci. 2006; 47:10241029. [PubMed: 16505037]

110. Kuehn MH, Kim CY, Ostojic J, et al. Retinal synthesis and deposition of complement components induced by ocular hypertension. Exp Eye Res. 2006; 83:620-628. [PubMed: 16677633] 


\section{Case Presentation: Primary Open-Angle Glaucoma}

\section{History}

A 71-year-old white woman was referred to an ophthalmologist because of declining vision. A diagnosis of glaucoma had been made 10 years earlier, with intraocular pressures $(\mathrm{mm} \mathrm{Hg})$ in the mid-20s. She underwent laser trabeculoplasty of the left eye before the referral and was treated with topical antiglaucoma medications (timolol and latanoprost) at the time of the referral. She had no other medical problems. Her 49-yearold nephew had glaucoma.

\section{Examination}

On ocular examination, her visual acuity was 20/25 in each eye. She also had mild cataracts in both eyes. Her iridocorneal angles were open, and the intraocular pressure was slightly elevated, at $22 \mathrm{~mm} \mathrm{Hg}$, in both eyes, on the two medications. Fundus examination revealed cupped optic disks, with superior notching of the cup in the right eye (Fig. 2A and 2B) and generalized thinning of the neuroretinal rim in the left eye (Fig. 2D and 2E). Automated perimetry testing (Humphrey Field Analyzer, Carl Zeiss Meditec) revealed corresponding loss of visual field in both eyes (Fig. 2C and 2F).

\section{Diagnosis and Management}

The diagnosis of primary open-angle glaucoma was confirmed. Given the extent of the optic-nerve damage and vision loss, further lowering of the intraocular pressure was recommended.

\section{Follow-up}

Over the course of the next 7 years, the patient underwent additional medical and surgical treatment for glaucoma (laser trabeculoplasty in the right eye and trabeculectomy in the left eye). At the last follow-up visit, her intraocular pressure was $18 \mathrm{~mm} \mathrm{Hg}$ in the right eye and $12 \mathrm{~mm} \mathrm{Hg}$ in the left eye, with stable visual fields. With her consent, she was screened for mutations in the gene encoding myocilin (MYOC) as part of a research study. She was found to have an $M Y O C$ Gln368Stop mutation. 


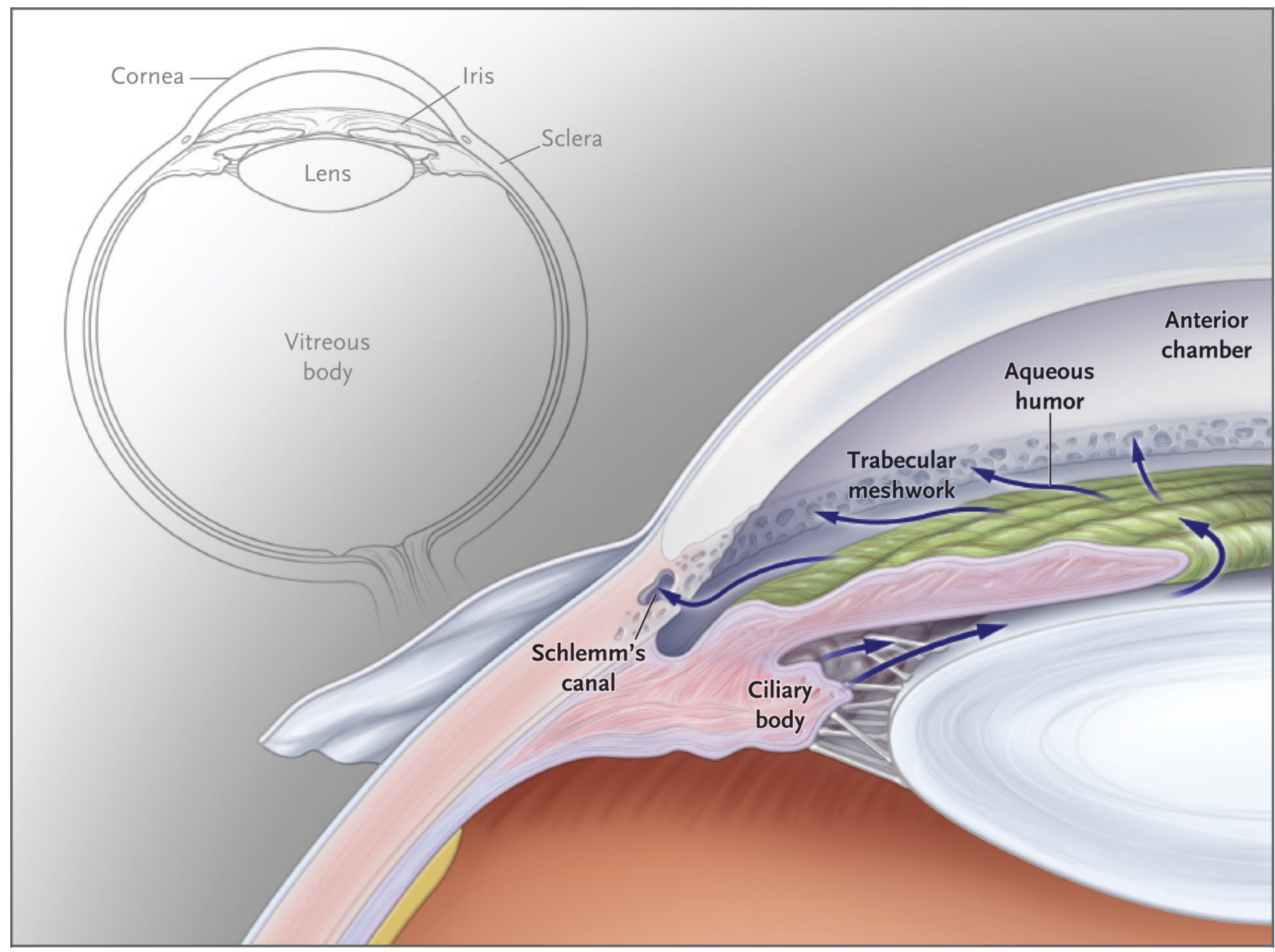

Figure 1. Circulation of the Aqueous Humor

This anterior segment of the eye shows the circulation of the aqueous humor from the ciliary body through the pupil into the anterior chamber. The aqueous humor then passes through the trabecular meshwork into Schlemm's canal and travels from there into the episcleral venous system. A smaller amount of aqueous humor leaves the eye through the face of the ciliary body, just below the trabecular meshwork. 


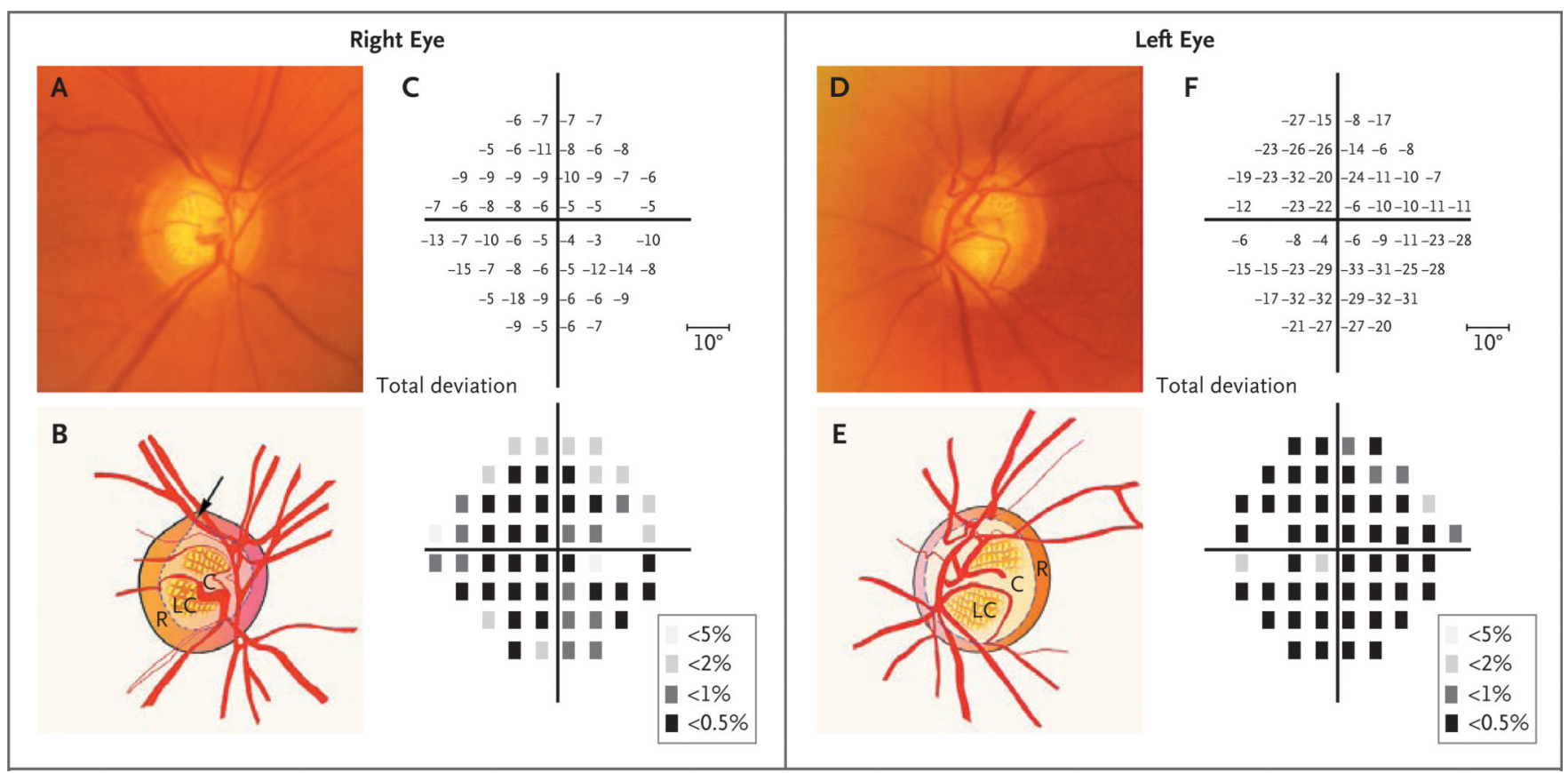

Figure 2. Optic Disks and Corresponding Visual Fields in a Patient with Primary Open-Angle Glaucoma and a MYOC Mutation

Panel A shows a photograph of the right optic disk, and the accompanying illustration in Panel B shows the superior notching (arrow) of the cup (C), which represents a focal loss of the neuroretinal rim (R). In addition, the lamina cribrosa (LC), a dense band of collagen and glial tissue within the cup that has multiple openings for nerve fiber bundles, has become visible because of the loss of overlying neuronal tissue. In Panel C, the results of Humphrey visual-field testing show the loss of visual field in total deviation plots. The upper plot shows the numerical deviation of individual test points, in decibels, from the values of a normative database adjusted for age, and the lower plot shows the probability of test points' being normal (the darker the square, the lower the probability). There is a substantial loss of visual-field sensitivity throughout, which is slightly worse inferiorly. The blank space in each plot represents the physiologic blind spot. Panel D shows a photograph of the left optic disk, with an accompanying illustration in Panel E, which shows generalized thinning of the $\operatorname{rim}(\mathrm{R})$, with enlargement of the cup $(\mathrm{C})$. The results of Humphrey visual-field testing, shown in Panel F, indicate the extensive visualfield loss in the left eye. 


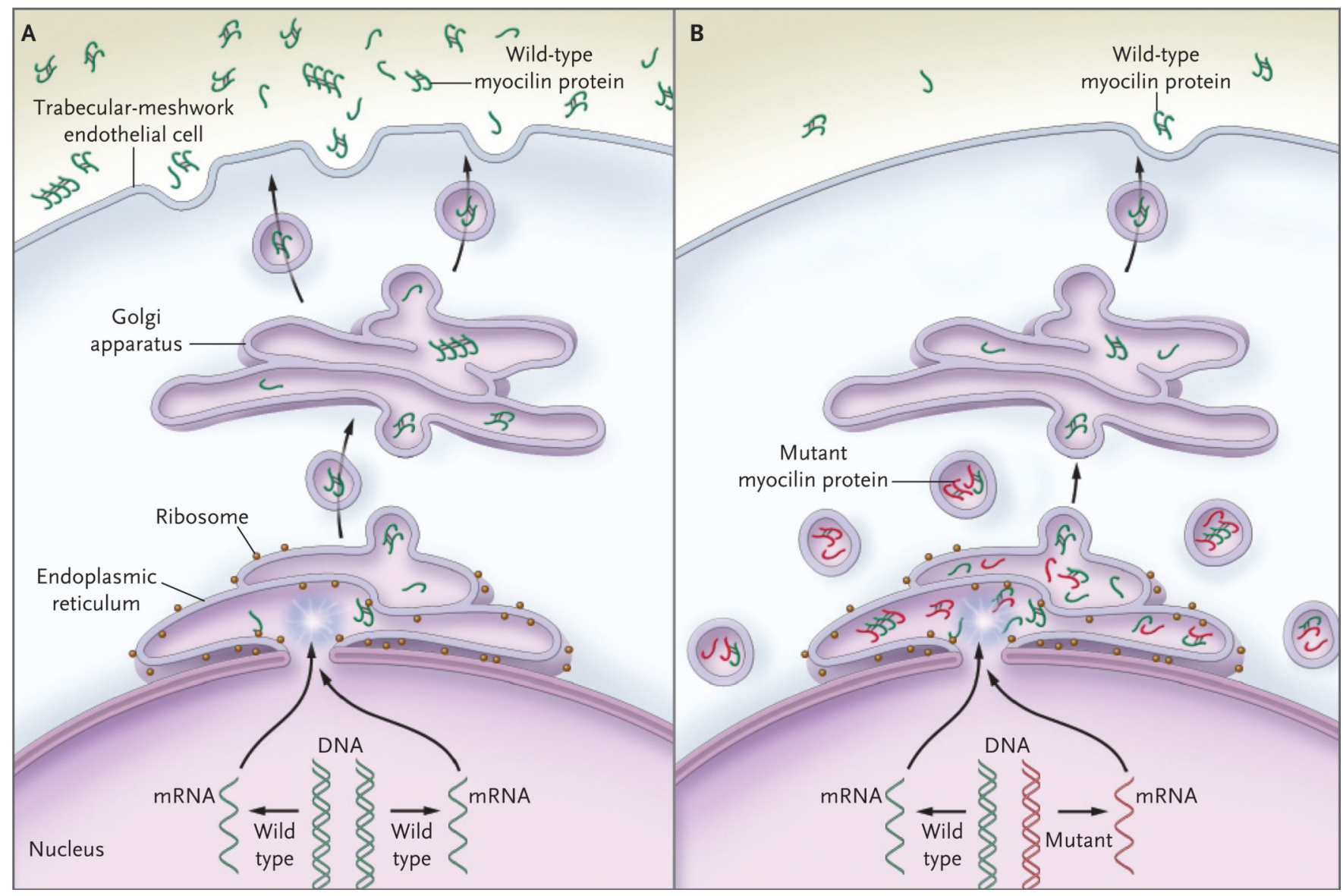

Figure 3. Proposed Pathways for Normal Secretion of Myocilin into the Aqueous Humor and for Secretion Reduced by a MYOC Mutation

In Panel A, wild-type myocilin protein (green symbols) is produced in the endothelial cells of the trabecular meshwork and passes through the secretory pathway to reach the extracellular space. In the first step in this process, messenger RNA (mRNA) is transcribed from the gene encoding myocilin (MYOC) and is delivered to ribosomes at the endoplasmic reticulum, where the mRNA directs the synthesis of myocilin. Next, transport vesicles convey myocilin to the cell membrane through the Golgi apparatus. These vesicles fuse with the cell membrane and release myocilin into the extracellular space and aqueous humor. Along the secretory pathway, molecules of myocilin may associate with each other and form multimers (dimers and tetramers are depicted). In Panel B, heterozygous mutations of the $M Y O C$ gene are associated with an autosomal dominant form of glaucoma. The wild-type copy of $M Y O C$ encodes normal myocilin protein (green symbols), and the mutant $M Y O C$ copy encodes mutant myocilin protein (red symbols). Myocilin protein forms multimers that may be composed of both wild-type and mutant subunits. Secretion of mutant myocilin protein and multimers containing mutant subunits is greatly reduced, leading to the retention of the mutant protein in the endoplasmic reticulum and intracellular vesicles of trabecularmeshwork cells. 


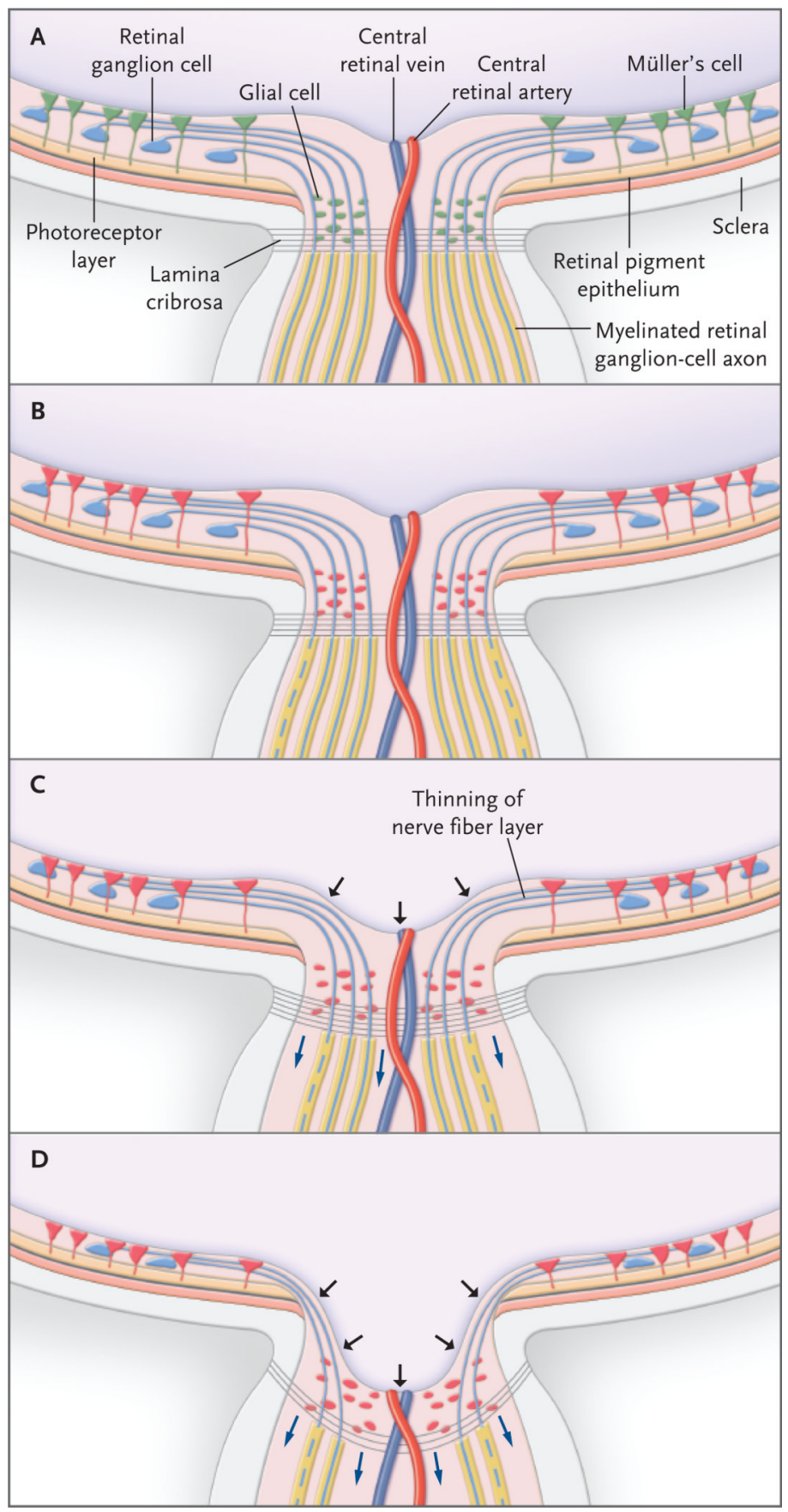

Figure 4. The Optic-Nerve Head and Proposed Events Leading to Retinal Ganglion-Cell Death in Glaucoma

In the normal optic-nerve head and retina (Panel A), retinal ganglion-cell axons exit the eye through the lamina cribrosa, becoming myelinated only in the postlaminar region. Glia in the retina (e.g., Müller's cells) and optic-nerve head (e.g., astrocytes and microglia) are quiescent (green). Increasingly elevated intraocular pressure puts stress on retinal ganglion cells, and glial cells become reactive (Panel B, red). Elevated intraocular pressure also leads to the production of a variety of substances, including tumor necrosis factor $a$, which in turn damage retinal ganglion-cell axons (dashed lines) at the lamina cribrosa. At this point there is no clinically detectable change in the cupping of the opticnerve head. Damage to retinal 
ganglion-cell axons is followed by cell (soma) death through apoptosis (Panel C). Loss of retinal ganglion cells and axon fibers results in thinning of the nerve-fiber layer. The lamina cribrosa itself undergoes remodeling, becoming thicker while bowing posteriorly (blue arrows), with increased cupping of the optic-nerve head (black arrows). In the advanced stage of glaucoma (Panel D), apoptosis and neuroinflammatory processes result in cell death and loss of most retinal ganglion cells and axons. The prelaminar tissue is substantially attenuated, and the lamina cribrosa becomes thinner and bowed more posteriorly (blue arrows), resulting in pronounced cupping of the optic-nerve head (black arrows). 
Table 1

Major Risk Factors Associated with Primary Open-Angle Glaucoma.

\begin{tabular}{|c|c|c|c|}
\hline Risk Factor & $\begin{array}{c}\text { Prevalence } \\
\text { of Glaucoma }\end{array}$ & $\begin{array}{l}\text { Relative Risk } \\
\text { of Glaucoma* }\end{array}$ & Source of Data \\
\hline \multicolumn{4}{|c|}{$\%$} \\
\hline Race & & & Rudnicka et al. ${ }^{8}$ \\
\hline Black & 4.2 & & \\
\hline White $^{\dagger}$ & 2.1 & & \\
\hline Asian & 1.4 & & \\
\hline Older age (odds ratio per decade increase) & & & Rudnicka et al. ${ }^{8}$ \\
\hline Black & & 1.6 & \\
\hline White $^{\dagger}$ & & 2.1 & \\
\hline Asian & & 1.6 & \\
\hline Elevated intraocular pressure & & & Sommer et al. ${ }^{9}$ \\
\hline$<15 \mathrm{~mm} \mathrm{Hg}$ & & 1.0 & \\
\hline $16-18 \mathrm{~mm} \mathrm{Hg}$ & & 2.0 & \\
\hline $19-21 \mathrm{~mm} \mathrm{Hg}$ & & 2.8 & \\
\hline $22-29 \mathrm{~mm} \mathrm{Hg}$ & & 12.8 & \\
\hline $30-34 \mathrm{~mm} \mathrm{Hg}$ & & 39.0 & \\
\hline Diastolic perfusion pressure (adjusted odds ratio) ${ }^{t}$ & & & Tielsch et al. ${ }^{10}$ \\
\hline $250 \mathrm{~mm} \mathrm{Hg}$ & & 1.0 & \\
\hline $40-49 \mathrm{~mm} \mathrm{Hg}$ & & 1.7 & \\
\hline $30-39 \mathrm{~mm} \mathrm{Hg}$ & & 2.1 & \\
\hline$<30 \mathrm{~mm} \mathrm{Hg}$ & & 6.2 & \\
\hline Family history in first-degree relative (adjusted odds ratio) & & 2.9 & Tielsch et al. ${ }^{11}$ \\
\hline Myopia (adjusted odds ratio) & & $1.6-3.3$ & Mitchell et al., ${ }^{12}$ Wong et al. ${ }^{13}$ \\
\hline Thin central cornea (hazard ratio per $40-\mu \mathrm{m}$ decrease) & & 1.7 & Gordon et al. ${ }^{14}$ \\
\hline
\end{tabular}

Data are relative risks unless otherwise specified.

${ }^{t}$ The category of white race includes Hispanics.

t Diastolic perfusion pressure is defined as diastolic blood pressure minus intraocular pressure. 